$\begin{array}{ll} & \text { Etnográfica } \\ \text { etnográfica } & \text { Revista do Centro em Rede de Investigação em }\end{array}$

Antropologia

vol. 15 (1) | 2011

Vol. $15(1)$

\title{
Emília Margarida Marques, Os Operários e as Suas Máquinas: Usos Sociais da Técnica no Trabalho Vidreiro
}

\section{Luísa Veloso}

\section{(2) OpenEdition \\ Journals}

\section{Edição electrónica}

URL: https://journals.openedition.org/etnografica/896

DOI: 10.4000/etnografica.896

ISSN: 2182-2891

\section{Editora}

Centro em Rede de Investigação em Antropologia

\section{Edição impressa}

Data de publição: 1 fevereiro 2011

Paginação: 206-208

ISSN: 0873-6561

\section{Refêrencia eletrónica}

Luísa Veloso, «Emília Margarida Marques, Os Operários e as Suas Máquinas: Usos Sociais da Técnica no Trabalho Vidreiro», Etnográfica [Online], vol. 15 (1) | 2011, posto online no dia 23 outubro 2011, consultado o 10 fevereiro 2022. URL: http://journals.openedition.org/etnografica/896 ; DOI: https:// doi.org/10.4000/etnografica.896

Etnográfica is licensed under a Creative Commons Attribution-NonCommercial 4.0 International License. 
(p. 152 e segs.), criando dois novos conceitos, particularmente interessantes para explicitar e compreender a complexidade e dialeticidade de poder existente entre os homens e as mulheres ciganas - os conceitos de dominação subordinada e de subordinação subordinante, eles próprios, como refere a autora, aplicáveis a outros domínios, a outras esferas da vida social.

Emília Margarida Marques

OS OPERÁRIOS E AS SUAS MÁQUINAS: USOS SOCIAIS DA TÉCNICA NO TRABALHO VIDREIRO

Lisboa, Fundação Calouste Gulbenkian/ /Fundação para a Ciência e a Tecnologia, 2009, 452 páginas.

Com este livro, Emília Margarida Marques publica a sua dissertação de doutoramento em Antropologia. Como é referido por Jorge Crespo no prefácio à obra, este livro decorre de um longo trabalho de terreno da autora sobre a indústria do vidro na Marinha Grande e enquadra-se na temática dos "usos sociais das técnicas”, que é problematizada convocando saberes teóricos e procedimentais de várias ciências sociais. Constitui, desde logo, um contributo fundamental, por abordar um assunto escassamente estudado em Portugal. Mais pertinente ainda se torna por se debruçar sobre o desempenho profissional de trabalhadores que exercem as suas funções com dispositivos técnicos automatizados, discutindo a sua apropriação.

A obra estrutura-se em sete capítulos. No primeiro a autora apresenta as motivações para a investigação que realizou, enquadrando-as no seu percurso pessoal e profissional na Marinha Grande. Avança
Entre os contributos inovadores da investigação de Maria José Casa-Nova, é de assinalar a sua atenção às reconfigurações dentro da cultura cigana, quer dizer, a historicidade dos processos em jogo, debaixo da tradição que cobre o rosto do seu véu identitário.

\section{Claire Auzias}

Socius-UTL

ainda com a discussão em torno dos escassos estudos existentes no domínio da antropologia das técnicas e do trabalho industrial. Trata-se, contudo, de uma abordagem sumária, parcialmente retomada no capítulo 2. Tal opção de apresentação em dois capítulos distintos exige ao leitor o trabalho de articulação dos vários contributos. Mas o cerne da questão, sublinhado pela autora, é a introdução do objeto máquina: "as utilizações da matéria na construção do social” (p. 51).

O capítulo 2 condensa uma análise acerca do lugar ocupado pela matéria e pelas técnicas na antropologia. A autora propõe um percurso histórico que remonta ao século XIX, evidenciando a valorização dos objetos como elementos de demonstração de especificidades culturais. No entanto, e como é referido, tal não deu desde logo origem a uma "antropologia das técnicas": "o objeto contava enquanto dado, na sua substância material de coisa acabada, não enquanto processo" (p. 55). Este capítulo é ainda estruturante desta obra por estabelecer as primeiras pontes com a "antropologia do consumo" (p. 77) dos objetos, isto é, a sua apropriação social. Embora da produção ao consumo vá uma distância considerável, impossível de encerrar neste livro, a autora lança algumas pistas nesse sentido. 
Assim, ganha destaque, de uma forma mais ampla, a dinâmica social de apropriação dos objetos.

O capítulo 3 é centrado nas abordagens (não exclusivamente antropológicas) das técnicas e dos seus usos sociais. E, neste domínio, é incontornável o trabalho de Latour e a "nobilitação" dos objetos como integrantes das redes constituídas por humanos e não-humanos. A autora problematiza, ainda, a matéria, a técnica como fonte de poder e de dominação. Também este eixo será estruturante na análise da indústria automatizada do vidro.

Estes três capítulos (em particular os capítulos 2 e 3) condensam os grandes eixos de reflexão que a autora procura mobilizar na análise. Note-se, aqui, a necessidade, para o leitor, de um trabalho de síntese e de articulação com o objeto de estudo apenas de uma forma parcial.

O capítulo 4 é dedicado às opções metodológicas de entrada na fábrica. Trata-se de uma reflexão muito rica e essencial na obra, na medida em que permite compreender a inscrição da investigação no espaço e no tempo, os instrumentos de análise acionados e os procedimentos de sistematização da informação, na medida em que "a pesquisa se faz tanto de impressionismo, sensorialidade e relação interpessoal, como de reflexão e abstração" (p. 141). Com este capítulo se faz a ponte para os dois capítulos que se seguem e que são o eixo central deste livro.

No capítulo 5 é apresentada a evolução histórica da indústria do vidro de embalagem na Marinha Grande. Este tem um anexo interessante de fotografias que permitem ficar com uma panorâmica do que é descrito ao longo do capítulo, com destaque para as transformações que marcam o espaço da fábrica entre o fabrico manual e o fabrico automatizado de garrafas e o enquadramento da evolução da indústria vidreira no percurso histórico da política industrial portuguesa. Destaca-se, neste capítulo, o facto de se assistir à estruturação de um grupo de profissionais - os vidreiros - marcado por uma estrutura hierárquica de trabalho de ofício e às transformações que foram tendo lugar, ao longo do século XX, em particular, com a introdução de máquinas. A técnica materializada teve consequências nas formas de identificação e de vivência da profissão de vidreiro, mas não retirou poder aos detentores de tal título profissional. Já nas décadas de 40 e 50, assiste-se à adesão ao sistema semiautomático de fabricação por parte dos ajudantes em início de carreira e não dos oficiais nem dos ajudantes altamente qualificados (p. 191). Verifica-se, deste modo, uma rotura com a hierarquia profissional passada (mas que não é total), a constituição de um "grupo qualificado, coeso e relativamente autónomo" (p. 193) e uma apropriação da máquina. O fim da Segunda Grande Guerra é marcado por um forte crescimento do desemprego e a introdução de máquinas automatizadas na indústria do vidro da Marinha Grande. No entanto, este processo é pleno de avanços e recuos de que autora dá conta e que marcam a história da indústria portuguesa.

É extremamente interessante o contributo desta obra para a construção social das profissões e das respetivas classificações profissionais, nomeadamente ao evidenciar a emergência dos "condutores de máquinas” (p. 223). A introdução de equipamento automatizado nesta indústria teve consequências visíveis ao nível da estrutura técnica, produtiva e organizacional das fábricas, da composição dos profissionais e das respetivas práticas de gestão (em domínios como o das remunerações e das carreiras), do conteúdo do trabalho, da formação e das identidades.

E é assim que a autora procede à transição para o capítulo 6, centrado nas alterações ocorridas com a introdução dos mecanismos 
automatizados. O texto é longo e rico do ponto de vista da análise, e persiste aqui a preocupação com a explicitação do trabalho etnográfico realizado. Neste capítulo, profícuo em detalhes sobre o processo produtivo, é notória a preocupação em dar conta da complexidade do real. Destacam-se aqui três eixos. O primeiro radica no facto de a matéria-prima em causa, o vidro, não ser estável. Sofre variações com consequências no produto final e constitui-se como um não-humano que exige uma intervenção humana; logo, persiste, com os mecanismos automatizados, um processo social de apropriação/manipulação da técnica. O segundo eixo é a relação entre os usos da técnica e os objetivos de rentabilização económica das empresas. O terceiro assenta nas margens de autonomia dos trabalhadores na gestão e divisão do trabalho, associadas à estruturação de hierarquias internas num processo que, numa leitura de senso comum, por ser automatizado, apontaria para uma forte rigidez e determinismo tecnológicos. Não se trata apenas de uma construção dos trabalhadores, decorre também das exigências do processo produtivo. Assim, por razões associadas às caraterísticas da matéria-prima, às exigências na condução das máquinas e da história da indústria do vidro na Marinha Grande, para referir apenas estes aspetos, soma-se à análise o processo, não apenas de uso social, mas de construção social do uso da técnica.

Este livro termina com um (talvez demasiado) breve texto em que se enfatiza a relevância da análise sobre os usos sociais das técnicas e se encerra o ciclo sugerindo, como já foi aqui referido, a prossecução da reflexão no âmbito da "antropologia dos consumos e da cultura material” (p. 359).

Esta constitui uma obra importante para a análise do trabalho nas ciências sociais, expondo uma pesquisa que se debruça sobre o desempenho do trabalho humano em relação com as técnicas, acompanhando o processo de automatização da indústria do vidro de embalagem.

Uma nota final para destacar a relevância e utilidade documentais dos anexos da obra, em particular para os dois primeiros: uma cronologia da evolução da indústria do vidro de embalagem em Portugal e um glossário da terminologia vidreira.

\section{Luísa Veloso}

ISCTE - Instituto Universitário de Lisboa, CIES-IUL 